Jurnal Agribis

Vol. 7, No.1, Tahun 2021

\title{
ANALISIS KEMANFAATAN USAHA TANI KACANG TANAH SISTEM TUMPANGSARI
}

\author{
Herry Nur Faisal ${ }^{1}$ \\ 1,Program Studi Agribisnis, Fakultas Pertanian, Universitas Kadiri \\ 2 \\ E-mail: herrynf81@gmail.com
}

\begin{abstract}
Peanuts are in the second most important position after soybeans in Indonesia, so they have the potential to be developed because peanuts have high economic value and have a large enough domestic market opportunity. Based on the area of cultivation, peanuts rank fourth after rice, corn and soybeans. The results of the study are as follows 1). Farmers spend a production cost of Rp. 3,865,500 in a farm scale of 1 ha per planting season. Production costs include the means of producing fertilizer, purchasing peanut seeds, transportation and costs of tillage until the harvesting process. The net income received by farmers in farming peanuts in the intercropping system is the value obtained from the proceeds from the sale of peanuts minus all costs incurred by farmers in farming so that the farm income is IDR 6,434,500. 2). The $B$ / $C$ ratio of peanut farming in one crop in the intercropping in the village of kacangan, ngunut sub-district, Tulungagung Regency,> 1 is 1.66 so it is feasible to cultivate.
\end{abstract}

Keywords: farming, economic benefits, peanuts, intercropping

\begin{abstract}
ABSTRAK
Kacang tanah menduduki posisi kedua terpenting setelah kedelai di Indonesia sehingga berpotensi untuk dikembangkan karena kacang tanah memiliki nilai ekonomi tinggi dan memiliki peluang pasar dalam negeri yang cukup besar.Berdasarkan luas pertanaman, kacang tanah menempati urutan ke empat setelah padi, jagung dan kedelai.Hasil dari penelitian sebagai berikut 1). Petani mengeluarkan biaya produksi sebesar Rp 3.865.500,- dalam ukuran skala usahatani 1 ha tiap satu kali musim tanam. Biaya produksi meliputi sarana produksi pupuk, pembelian benih kacang tanah, transportasi dan biaya pengolahan tanah sampai proses pemanenan. Pendapatan bersih yang diterima petani dalam berusahatani kacang tanah pada system tumpangsari merupakan nilai yang didapatkan dari hasil penerimaan penjualan kacang tanah dikurangi dengan semua biaya yang dikeluarkan oleh petani dalam usahatani sehingga pendapatan usahatani sebesar $\mathrm{Rp} 6.434 .500,-$. 2). Rasio B/C usahatani kacang tanah dalam satu kali tanam pada tumpangsari di Desa kacangan kecamatan ngunut Kabupaten Tulungagung $>1$ yaitu 1,66 sehingga layak untuk diusahakan.
\end{abstract}

Kata Kunci : usaha tani, manfaat ekonomi, kacang tanah, tumpang sari 


\section{PENDAHULUAN}

Kacang tanah di Negara Indonesia memiliki potensi yang cukup tinggi untuk dikembangkan hal ini karena dirasa kacang tanah memiliki nilai ekonomi yang bagus, sehingga mampu memberikan peluang pasar yang cukup besar. Sehingga jika kita dapat mengambil kesimpulan, kacang tanah berada diposisi kedua setelah kedelai sebagai tanamn polong-polongan yang cukup berpotensi di Indonesia.

Pemerintah tengah berupaya melakukan bentuk pembangunan di sentra pertanian dengan membentuk sentra agribisnis pada sebuah wilayah yang memiliki komoditi yang bisa dikembangkan dan mampu memberikan kontribusi besar bagi keberlangsungan peningkatan ekonomi masyarakat petani.Sentra pada suatu wilayah agribisnis ini merupakan sebuah wilayah yang memiliki komitmen untuk mengembangkan sistem agribisnis suatu komoditas wilayahnya sehingga mampu menjadikan komoditas tersebut menjadi komoditas unggulan.Kontribusi di masing-masing daerah diharapkan bisa berasal dari subsistem hulu, usaha tani, hilir, serta pemasaran yang optimal.ika Selatan.Dengan pengelolaan ilmu pengetahuan dan tehnologi yang benar, lahan di dataran rendah memiliki prospek yang cukup bagus untuk dikembangkan menjadi lahan pertanian agar lebih produktif.

System usaha pengembangan agribisnis kacang tanah dengan menggunakan metode tumpangsari dirasa menjadi sebuah terobosan baru dan mampu memberikan peningkatan penghasilan dari para petani kacang tanah.System tumpangsari yang dimaksudkan adalah menanam dua jenis komoditas dalam satu lahan. Dari upaya yang dilakukan sebagai upaya untuk mengembangan peningkatan produksi kacang tanah besar harapan dapat mampu menopang serta memperbaiki perekmonomian petani sehingga mereka tidak meninggalkan pekerjaannya untuk meninggalkan pekerjaan lain.

Upaya peningkatan produksi kacang tanah guna mneuju ketahanan pangan nasional dan juga sebagai usaha mengembangkan peningkatan seabagi lahan pertanian yang lebih produktif dengan meningkatkan pendapatan petani kacang tanah.Untuk itu penulis melakukan penelitian mengenai analisis kemanfaatan produksi kacang tanah dengan system tumpangsari. 


\section{METODE PENELITIAN}

\section{Waktu dan Lokasi Penelitian}

Penelitian ini dilakukan bulan April-september 2019.Lokasidilaksanakan di Desa Kacangan Kecamatan Ngunut Kabupaten Tulungagung. Peneliti memilih lokasi penelitian dengan cara sengaja (purposive sampling).Dengan menggunakan metode ini peneliti secara sengaja menjadikan Desa Kacangan Kecamatan Ngunut sebagai lokasi penelitian dikarenakan di Desa Kacangan terdapat banyak masyarakat yang menanam kacang tanah dengan menggunakan metode tumpangsari jagung dan kacang tanah.

\section{Jenis Penelitian dan Sumber Data}

\section{a. Jenis Penelitian}

Peneliti menggunakan analisis deskriptif dengan metode survey dengan menggunakan kuisioner sebagai acuan untuk menggali informasi kepada responden. Pada penelitian ini, peniliti akan menjelaskan secara sistematis (Singarimbun, 1995).

\section{b. Sumber Data}

1. Data Primer

Data primer diperoleh dari data yang diambil secara langsung serta kongkrit dan juga actual dari sumbernya, yakni pertain kacang tanah diwilayah sasaran.

- Metode Survey, peneliti menggali informasi dengan menggunakan kuisioner yang berisi mengenai kumpulan pertanyaan mengenai variable yang terkait pada penelitian yang dilakukan.

- Metode Observasi merupakan sebuah metode yang dilakukan oleh peneliti dengan langkah mengumpulan data dengan mengamati secara langsung

\section{Data Sekunder}

Peneliti secara tidak langsung mecari data penelitian melalui media yang diperoleh dari pencatatan oleh pihak lain. Data yang didapatkan dijadikan seabagi literature serta sumber yang akan mendukung akan keberlangsungan penelitian ini.

Data sekunder biasanya dalam bentuk bukti, catatan atau laporan historis yang tersusun dalam sebuah arsip (data dokumenter) dan telah 
dipublikasikan dan tidak dipublikasikan yang berguna sebagai tambahan argumen logis.

\section{Metode Pengambilan Sampel}

Peneliti menggunakan metode pengambilan sampel secara purposive (sengaja). Populasi yang dimaksudkan merupakan sebagian atau keseluruhan dari unsur-unsur yang mempunyai satu ciri, beberapa ciri atau karakteristik yang sama. Dalam populasi ini sebagai populasinya adalah masyarakat Desa Kacangan yang menanam kacang tanah pada masa tanam pada bulan April-September 2019 sejumlah 80 orang.

\section{Metode Pengumpulan Data}

Teknik pengambilan data di lapangan menggunakan:

a. Wawancara

Peneliti menggunakan tehnik wawancara pada proses pengambilan datanya, peneliti akan menggali informasi secara langsung kepada responden berdasarkan guidline yang telah disiapkan peneliti.

Alat bantu yang dipakai pada penelitian ini dengan menggunakan kuesioner, dan penulis juga menggunakan interview atau wawancara tak terstruktur dengan mengajukan pertanyaan secara bebas dan leluasa seputar masalah dalam penelitian.

b. Dokumentasi

Pendokumentasian yang dilakukan dengan cara mengumpulan data dengan mencatat data sekunder yang telah tersedia berupa data-data tentang produksi kacang tanah di dataran rendah.

c. Observasi/Pengamatan

Peneliti mengambil data dengan melakukan pengamatan secara langsung pada obyek yang serta mencatat pada system terhadap gejala yang terkait dalam kajian penelitian ini.

d. Studi kepustakaan

Sebuah teknik pengumpulan data dengan penelaahan pustaka atau telaah laporan-laporan yang berasal dari instansi terkait.Sehingga dengan adanya studi kasus diharapkan dapat dijadikan acuan oleh peneliti.

\section{Metode Analisa Data}

Metode analisis data yang dijadikan peneliti pada penelitian adalah :

a. Untuk mengetahui pendapatan petani pada usahatani kacang tanah di dataran rendah menurut Hadisapoetra, 1973 adalah sebagai berikut : 


$$
\begin{aligned}
\mathrm{PdU} & =\mathrm{PrU}-\mathrm{BM} \\
& =\mathrm{H} \times \mathrm{Y}-\mathrm{BM} \\
\mathrm{Keterangan}: & \\
\mathrm{PdU} & =\text { Pendapatan usahatani kacang tanah }(\mathrm{Rp} / \mathrm{Ha} / \mathrm{Th}) . \\
\mathrm{PrU} & =\text { Penerimaan Usahatani kacang tanah }(\mathrm{Rp} / \mathrm{Ha} / \mathrm{Th}) . \\
\mathrm{BM} & =\text { Biaya mengusahakan usahatani kacang tanah }(\mathrm{Rp} / \mathrm{Ha} / \mathrm{Th}) . \\
\mathrm{H} \quad & =\text { Harga produksi usahatani kacang tanah }(\mathrm{Rp} / \mathrm{Kg}) . \\
\mathrm{Y} \quad & =\text { Hasil produksi usahatani kacang tanah }(\mathrm{Kg}) .
\end{aligned}
$$

b. Untuk mengetahui kemanfaatan ekonomi pada usahatani kacang tanah digunakan rumus analisis Increamental Benefit Cost Ratio $(\mathrm{B} / \mathrm{C})$ menurut Soekartawi (2001) sebagai berikut :

$$
\text { Increamental } B / C \text { Ratio }=\frac{\Delta P r}{\Delta B u}
$$

Increamental B/C Ratio = manfaat ekonomi pada usahatani kacang tanah Keterangan :

$\Delta \mathrm{Pr}=$ Selisih antara penerimaan usahatani kacang tanah $(\mathrm{Rp} / \mathrm{Ha} / \mathrm{Th})$.

$\Delta \mathrm{Bu}=$ Selisih antara biaya usahatani kacang tanah $(\mathrm{Rp} / \mathrm{Ha} / \mathrm{Th})$.

Keterangan kriteria dari rumus analisis Increamental Benefit Cost Ratio diatas sebagai berikut :

a) Increamental $B / C$ Ratio $>1$, berarti usahatani kacang tanah pada dataran rendah lebih bermanfaat dibanding dengan usahatani tanaman lainnya.

b) Increamental $B / C$ Ratio $\leq 1$, berarti usahatani kacang tanah pada dataran rendah tidak bermanfaat dibandingkan dengan usahatani tanaman lainnya.

\section{HASIL DAN PEMBAHASAN}

\section{Hasil Produktivitas Kacang Tanah pada Sistem Tumpangsari}

Tumpang sari merupakan sebuah sistem bercocok tanam yang memanfaatkan dua jenis tanaman atau lebih yang berbeda dengan tujuan untuk meminimalisir terjadinya kerugian akibat berbagai faktor biotik dan abiotic ataupun harga pasar. Pada pola tanam kacang tanah ditanam terlebih dahulu kemudian jagung.tahap-tahap yang dapat dilakukan pada proses tumpang sari yaitu: pengolahan tanah, penanaman, pemupukan, pemeliharaan tanaman, pemanenan 
Keuntungan yang diperoleh dari sistem tumpangsari adalah petunia kan mendapatkan hasil bercocok tanam tidak hanya pada satu komoditas saja namun terdapat dua komditas yang hal tersebut bisa menambah pendapatan petani dan harapannya adalah mampu mengupayakan pada tahap peningkatan perekonomian masyarakat petani pada suatu wilayah tertentu.

Didalam sebuah sistem tumpangsari terdapat beberapa elemen yang tidak dapat dipisahkan pada saat proses bercocok tanam diantaranya adalah tenaga kerja. Terdapat perbedaan upah bagi tenaga kerja, pada tenaga kerja wanita umumnya $50 \%$ lebih kecil dari upah tenaga kerja pria, hal ini disebabkan oleh beberapa faktor diantaranya adalah produktivitas dari tenaga kerja pria. Peran wanita tidak maksimal karena mereka memiliki peran ganda yang harus menjadi ibu rumah tangga dan membantu bercocok tanam.

Pembagian peran dalam system bercocok tanam pada pengolahan kacang tanah ini memberikan pengaruh pada hasil pengelolaan kacang tanah, yang mana dengan adanya system tumpangsari mampu memberikan tambahan penghasilan bagi petani kacang tanah, yang mana keuntungan yang diperoleh tidak hanya berasal dari satu komoditas lainnya.

Sarana produksi yang diperlukan dalam proses produksi kacang tanah pada dataran rendah. Untuk penggunaan bibit kacang tanah jenis gajah dan pupuk yang digunakan SP36.

Dari hasil data yang diperoleh dari lapang melalui proses wawancara, diperoleh informasi dengan melihat hasil pengeluaran petani pada biaya produksi pada sistem tumpangsari di Desa Kacangan Kecamatan Ngunut Kabupaten Tulungung, petani mengeluarkan biaya produksi sebesar Rp 3.865.500,- dalam ukuran skala usahatani 1 ha tiap satu kali musim tanam. Biaya produksi ini meliputi beberpa hal diantaranya adalah sarana produksi pupuk, pembelian benih kacang tanah, transportasi dan pengolahan tanah sampai proses panen.

Penerimaan dan pendapatan usahatani kacang tanah merupakan jumlah pemasukan yang diterima petani yang didapatkan dari perkalian antara jumlah produksi kacang tanah yang dihasilkan dengan harga kacang tanah per $\mathrm{kg}$ sebesar $\mathrm{Rp} 4.500$,-/kg. Jumlah penerimaan usahatani kacang tanah yang dilakukan petani sebesar Rp 10.350.000,-. Jumlah tersebut didapat dari perkalian antara jumlah produksi kacang tanah yang diterima petani sebesar $2300 \mathrm{~kg}$ dengan harga kacang tanah tiap kilogramnya Rp 4.500,-. Maka 
didapatkan pendapatan bersih yang diterima oleh petani dalam berusahatani kacang tanah pada tumpangsari merupakan nilai yang didapatkan dari hasil penerimaan penjualan kacang tanah dikurangi dengan semua biaya yang dikeluarkan oleh petani dalam usahatani sehingga pendapatan usahatani kacang tanah sebesar Rp 6.434.500,-.

Usahatani pada pola tanam tumpangsari merupakan suatu bentuk usahatani yang terdiri dari dua tanaman dengan pengelolaan usahatani yang berbeda dalam satu tahun pada lahan dataran rendah dengan luas yang sama, yaitu jagung tumpangsari dengan kacang tanah.

Menurut hasil penelitian pada pola tanam tumpangsari kacang tanah awal pertumbuhan terjadi persaingan antar tanaman dalam menyerap unsur hara dan cahaya sehingga pertumbuhan kurang baik.Namun untuk mengatasi hal tersebut petani melakukan antisipasi dengan berbagai cara diantaranya dengan nembahkan unsur hara dengan menggunakan pupuk supaya dapat memenuhi kebutuhan dari kedua tanaman yang ditanam dengan menggunakan system tumpangsari..

Pada tanaman kacang tanah yang ternaungi akan menjadi lebih lemah jika dibandingkan dengan tanaman lainnya. Hal ini disebabkan karena tanaman kacang tanah akan tumbuh dibwah naungan sehingga menyebabkan daun-daunnya lebih tipis sehingga tingkat kapasitas fotosintesisnya menjadi lebih rendah. Untuk daun-daun yang menerima cukup cahayaakan memiliki kloroplas dan jaringan palisade yang banyak dan kapasitas fotosintesis per luasan daun tinggi.

\section{Analisis Benefit Cost Ratio Usahatani Kacang Tanah Sistem Tumpangsari}

Peneliti melakukan uji kelayakan serta manfaat untuk usahatani pada kacang tanah dengan menggunakan system tumpangsari.Hal ini dilakukan untuk melihat apakah layak dilakukan usahatani tersebut di Desa Kacangan Kecamatan Ngunut Kabupaten Tulungagung. Peneliti melakukan sebuah analisis salah satunya dapat dilihat dari rasio perbandingan antara keuntungan atau pendapatan dengan total biaya usaha pada komoditas kacang tanah dengan cara tanam tumpangsari.

Rata-rata keuntungan dalam satu kali musim tanam pada kacang tanah dengan sistem tumpangsari di Desa Kacangan Kecamatan Ngunut Kabupaten Tulungagung sebesar $\mathrm{Rp} 6.434 .500,-/$ musim tanam yang diperoleh dari 
selisih antara rata-rata penerimaan dengan rata-rata total biaya. Nilai $B / C$ Ratio yang diperoleh yaitu 1,66/musim tanam, nilai ini diperoleh dari hasil bagi antara rata-rata pendapatan usahatani kacang tanah dengan rata-rata total biaya usahatani kacang tanah tersebut.

Dari kriteria yang digunakan adalah jika B/C Ratio > 1 maka usahatani kacang tanah pada tumpangsari layak diusahakan. Berdasarkan B/C Ratio pada tempat penelitian yaitu di Desa Kacangan Kecamatan Ngunut Kabupaten Tulungagung sebesar 1,66> 1 sehingga dapat dikatakan bahwa usahatani kacang tanah pada tumpangsari yang dilakukan layak untuk diusahakan. Nilai Benefit Cost Ratio ini menggambarkan bahwa setiap 1 rupiah pengeluaran dalam usahatani kacang tanah yang dilakukan tersebut menghasilkan 1,66 satuan pendapatan.

\section{KESIMPULAN DAN SARAN}

\section{KESIMPULAN}

Kesimpulan yang dapat diambil dari penelitian yang tengah dilakukan oleh peneliti adalah sebagai berikut:

1. Petani mengeluarkan biaya produksi sebesar $\mathrm{Rp} 3.865 .500$,- dalam ukuran skala usahatani 1 ha tiap satu kali musim tanam. Biaya produksi meliputi sarana produksi pupuk, pembelian benih kacang tanah, transportasi dan biaya pengolahan tanah sampai proses pemanenan. Kemudian untuk pendapatan bersih yang diterima petani dalam berusahatani kacang tanah pada system tumpangsari merupakan nilai yang didapatkan dari hasil penerimaan penjualan kacang tanah dikurangi dengan biaya yang digunakan oleh petani sehingga pendapatan usahatani sebesar $\mathrm{Rp} 6.434 .500$,-

2. Rasio $B / C$ usahatani kacang tanah dalam satu kali tanam pada tumpangsari di Desa Kacangan Kecamatan Ngunut Kabupaten Tulungagung $>1$ yaitu 1,66 sehingga layak untuk diusahakan.

\section{S AR A N:}

Saran dari hasil penelitian ini adalah dapat dijadikan acuan bagi peniliti yang lain dan juga dapat memberikan gambaran kepada masyrakat petani kacang tanah secara luas. Dari penlitian ini juga diharapkan mampu memberikan penignktan mutu 
Sumber Daya Manusia sehingga petani mampu membuat sebuah system baru yang lebih mmeberikan nilai manfaat yang lebih tinggi.

\section{DAFTAR PUSTAKA}

Adisarwanto, T. 2007. Meningkatkan Produksi Kacang Tanah di Lahan Sawah dan Lahan Kering. PT. Penebar Swadaya: Jakarta

Andrianto, et.al. 2004. Budidaya dan Analisa Usahatani Kacang Tanah. Absolut: Yogyakarta

Boediono. 2000. Pengertian Sederhana Mengenai Investasi. Jakarta

Hadisapoetra. 1973. Biaya dan Pendapatan di Dalam Usahatani. UGM: Yogyakarta

Hernanto, Fadholi. 1993. Ilmu Usahatani. Penebar Swadaya: Jakarta

Kasno, A. 2005.Strategi Pengembangan Kacang Tanah di Indonesia. Peningkatan

Produksi Kacang-Kacangan dan Umbi-Umbian Mendukung

Kemandirian Pangan.Badan Penelitian dan Pengembangan

Pertanian.Pusat Penelitian dan Pengembangan Tanaman Pangan: Bogor

Marzuki, H.A.R. 2007.Bertanam Kacang Tanah. Edisi Revisi, Penebar Swadaya: Jakarta

Pitoyo, et.al. 2003. Benih Kacang Tanah. Penerbit Kanisius: Yogyakarta

Singarimbun, Masri. 1995. Metode Penelitian Survey. LP3ES: Jakarta

Singarimbun, M dan S.Efendi. 1989. Metode Penelitian Survei. LP3ES: Jakarta

Soekartawi. 1990. Teori Ekonomi Produksi, dengan Pokok Bahasan Analisis Fungsi Cobb-Douglas. Rajawali Press: Jakarta

Sugiyono. 2000. Metode Penelitian Kualitatif dan R\&D. Alfabeta: Bandung

Sukirno, Sadono. 2000. Ekonomi Makro. Raja Grapindo Persada: Jakarta 